\title{
Innovation of History Learning Based on Live Virtual Learning Through The Utilization of Megalitic Relics in Desa Pakraman Selulung, Kintamani, Bali
}

\author{
I Made Pageh ${ }^{1}$ dan I Wayan Pardi ${ }^{1}$ \\ made.pageh@undiksha.ac.id,wayan.pardi@undiksha.ac.id \\ ${ }^{1}$ Universitas Pendidikan Ganesha, Indonesia
}

\begin{abstract}
The purpose of this study is to analyze the megalithic relics in Desa Pakraman Selulung and to formulate a historical learning model based on live virtual learning. This study uses a qualitative research method whose steps include determining the location of the study, data collection methods, data validity testing methods, and data analysis methods. In Desa Pakraman Selulung there are various ancient relics of the megalithic era including the Megalithic Statue, Menhir, Punden Berundak, and Sarcophagus. The stages of implementing history learning based on live virtual learning through the use of megalithic relics in Desa Pakraman Selulung, namely the preparation (planning), implementation process, and evaluation stages. History learning based on live virtual learning provides convenience for students, namely teaching and learning activities can be carried out anywhere and anytime, at low cost, student learning time becomes more flexible and more relaxed, and provides the widest opportunity for students to develop their knowledge. Through live virtual learning, it is also able to present megalithic relics in Desa Pakraman Selulung in a more real way into classes virtual, thereby improving the quality of learning and making it easier for students to absorb every material presented by the lecturer.
\end{abstract}

Keywords: History Learning, Live Virtual Learning, Megalithic Relics

\section{Introduction}

The classic problem faced by history lessons is that there is a very strong impression among students that history subjects are rote, less interesting, and boring subjects (Sayono, 2013: 9). ; Garvey and krug, 2015: 18). The lack of teacher skills in creating a creative, innovative, and fun learning atmosphere causes history lessons to be grouped as "periphery"(soft subjects) compared to certain subjects that are considered "main" (hard subjects). Whereas history lessons occupy a very important position in the formation of a dignified national character and civilization as well as in the formation of Indonesian people who have a sense of pride and love for the homeland (Habsari, 2015: 06).

In principle, each generation has its own style and characteristics in learning. The current generation is often referred to as "Generation $Z$ " is the generation that was born when technology and information had developed very sophisticated and entered all aspects of life. 
Teaching Generation $\mathrm{Z}$ will be very difficult if history teachers still apply traditional teaching styles, such as using the "Sitting Listening Recording Memorizing" method (Purnomo, et al., 2016: 71). In addition, other problems faced in history learning are teachers only use textbooks, worksheets, and Microsoft Power Point in the history learning process, learning methods only use the lecture method, teachers do not optimize the use of historical sources around students and teachers are less proficient in using technology as a medium for learning history.

According to the research results of Ahmad and Nelson Jinggan (2015: 8) stated that the proficiency and skills of history teachers in using technology as a learning medium will have a significant effect on increasing student motivation and learning outcomes. Moreover, in the Industrial Revolution 4.0 era, all aspects of human life demand efficiency, digitization and optimization (Saleh, et al, 2018: 253) so that it becomes a golden opportunity for history teachers in utilizing technology in the learning process. Therefore, the use of technology in learning can be an alternative solution to various educational problems, especially problems in learning history and teaching Generation Z. Moreover, Generation Z's learning environment is "not only the real world, but also the virtual world" (Purnomo, et al., 2016: 71).

One of the innovations that can be offered to attract students' interest in learning is through the use of live virtual learning in history learning. Virtual learning in principle is a learning activity that utilizes electronic media and internet networks (Subir, 2020: 24). Meanwhile, live virtual learning is defined as a learning process that occurs in the virtual world (virtual) directly (live) by utilizing electronic media, internet networks and-based applications online, or in other words, live virtual learning is a learning process that takes place in the virtual world in real time.

History learning through live virtual learning is increasingly seen as urgency when it is associated with the COVID-19 pandemic situation. The Covid-19 pandemic has forced educational institutions to change the learning system from face-to-face (conventional) to online (Nengrum, et all., 2021: 3). Online learning is learning to use the Internet network accessibility, connectivity, flexibility, and the ability to generate different types of learning interactions (Lisman, etal.,2021: 73). Learning through Online teaching and learning activities are still allowed to do despite social restrictions (social distancing) and distant (physical distancing) in education.

History learning innovations through live virtual learning can be done by utilizing historical learning resources that are close to students or teachers. One of them is by utilizing megalithic relics in the Desa Pakraman Selulung, Kintamani, Bangli. In the Desa Pakraman Selulung, there are various relics of diversion, such as Punden Berundak, Sarcophagus, Megalithic Statues, and Menhirs. In this millennial era or during the covid-19 pandemic, these relics can potentially be used as sources for learning history. This is in line with the function of ancient relics, namely the function of spectacle and the function of guidance. The function spectacle refers to the function of ancient relics as a recreational facility, which brings pleasure, inner and outer pleasure, gives a sense of beauty and satisfaction to many people. Meanwhile, the guidance function is the function of ancient relics in their position as directors and mentors for those who use them as sources of education, learning resources, sources of knowledge, as teaching aids or visualizations to find or re-attend various events, events or activities of the perpetrators in the past. .

Based on the above background, the purpose of this study is to analyze megalithic relics in Desa Pakraman Selulung and formulate a historical learning model based on live virtual learning through the utilization of megalithic relics in Desa Pakraman Selulung.

\section{Method} include:

The method used in writing this article is a qualitative research method, the steps 
1. The method of determining the research location. The location of this research is in Desa Pakraman Selulung, Kintamani District, Bangli Regency, Bali Province. Desa Pakraman Selulung is a combination of two service villages, namely Belantih Service Village and Selulung Service Village.

2. Data collection methods. The data collection methods that the author uses in writing this article are observation techniques, interview techniques and document study techniques. The observation technique was carried out on megalithic objects found in the temples of Desa Pakraman Selulung. Then, the interview technique was conducted on community leaders who have historical, cultural and religious knowledge aboutrelics megalithicand temples in Desa Pakraman Selulung. Meanwhile, the document study technique is carried out by analyzing the results of research that has been carried out by archaeologists, history and culture experts on megalithic relic's in Desa Pakraman Selulung.

3. The method of testing the validity of the data. In testing the validity of the data, the author uses triangulation techniques, namely triangulation of methods, theories, and data sources. Triangulation is defined as a data collection technique that combines various data collection techniques and existing data sources (Sugiyono, 2009: 241).

4. Data analysis method. The data analysis technique used in writing this article is an interactive analysis technique, in every data obtained from the field is always interacted or compared with other data units, the steps include data reduction (data reduction), display data (data display), and draw conclusions and verification (conclusion drawing/verification).

\section{Results And Discussion}

\section{A. ANCIENT LEGACY IN DESA PEKRAMAN SELULUNG}

Desa Pakraman Selulung is one of Desa Bali Aga/ Ancient who are in the district of Kintamani, Bangli, Bali (Sutedja and Muliarsa, 1990: 1). It is classified as one of the ancient villages because it is marked by the surviving remnants of ancient culture which are still believed to be used as a guide in living life in an effort to find a harmonious and balanced life. Remnants of ancient culture that can still be found in the Desa Pakraman Selulung include Megalithic Statues, Chinese/Chinese statues, Menhirs, building elements in the form of Tugeh with buffalo horn motifs, Punden terraces and so on (Susila, et al, 2007: 1).

The following are the characteristics of the archaeological remains found in the Desa Pakraman Selulung.

Tebel 1. Archaeological remains in the village of Pakraman Selulung

No.

Archaeological Relics

1. Punden Berundak Pelinggih I Ratu Gede Kemulan

2. Punden Berundak Pelinggih I Ratu Dukuh Jegir

3. Punden Berundak Pelinggih I Ratu Gede Kanginan

4. Punden Berundak Pelinggih I Ratu Gede Makarang

5. Punden Berundak Madya Petirtaan
Period

Megalithic/Prehistoric

Megalithic/Prehistoric

Megalithic/Prehistoric

Megalithic/Prehistoric

Megalithic/Prehistoric

$\begin{array}{lc}\text { Location } & \text { Amoun } \\ \text { Candi } & \text { t } \\ \text { Temple } & 1 \\ \text { Candi } & 1 \\ \text { Temple } & \\ \text { Mihu } & 1 \\ \text { Temple } & \\ \text { Mihu } & 1 \\ \text { Temple } & \\ \text { Bale } & \\ \text { Agung } & 1 \\ \text { Temple } & \end{array}$


6. Arca Megalithic

7. Menhir

8. Menhir

9. Sarcophagus

10. Ornament buffalo horn in Bale Tugeh

11. Natural Stone

12. Natural Stone

13. Natural Stone

14. Stone Slab

15. Shell (Sungu)

16. Chinese-style statue

17. Hindu-styled statue

18. Bronze Statue

19. Lingga Yoni

20. Lingga Fragment

21. A Set of Ancient Gamelan Gambang

22. A Set of Gamelan Selonding

23. A Set of Gamelan Gong Gede

24. Menhir in a Falling State

25. Store Shaped Wheels

Description:

$$
\text { ***: Polynomial / Hard calculated }
$$

\begin{tabular}{|c|c|}
\hline Megalithic/Prehistoric & $\begin{array}{l}\text { Ulun Suwi } \\
\text { Temple }\end{array}$ \\
\hline Megalithic/Prehistoric & $\begin{array}{l}\text { Ulun Suwi } \\
\text { Temple }\end{array}$ \\
\hline Megalithic/Prehistoric & $\begin{array}{l}\text { Puseh } \\
\text { Sinunggal } \\
\text { Temple }\end{array}$ \\
\hline Megalithic/Prehistoric & $\begin{array}{l}\text { People's } \\
\text { garden }\end{array}$ \\
\hline History /Literacy & $\begin{array}{l}\text { Most of the } \\
\text { temple }\end{array}$ \\
\hline Megalithic/Prehistoric & $\begin{array}{l}\text { Ulun Suwi } \\
\text { Temple }\end{array}$ \\
\hline Megalithic/Prehistoric & $\begin{array}{l}\text { Mas } \\
\text { Temple }\end{array}$ \\
\hline Megalithic/Prehistoric & $\begin{array}{l}\text { Mihu } \\
\text { Temple }\end{array}$ \\
\hline Megalithic/Prehistoric & $\begin{array}{l}\text { Mihu } \\
\text { Temple }\end{array}$ \\
\hline History /Literacy & $\begin{array}{l}\text { Mihu } \\
\text { Temple }\end{array}$ \\
\hline History /Literacy & $\begin{array}{l}\text { Taulan } \\
\text { Temple }\end{array}$ \\
\hline History /Literacy & $\begin{array}{l}\text { Arca } \\
\text { Sabang } \\
\text { Temple }\end{array}$ \\
\hline History /Literacy & $\begin{array}{l}\text { Pasek } \\
\text { Temple }\end{array}$ \\
\hline History /Literacy & $\begin{array}{l}\text { Taman } \\
\text { Temple }\end{array}$ \\
\hline History /Literacy & $\begin{array}{l}\text { Taulan } \\
\text { Temple }\end{array}$ \\
\hline History /Literacy & $\begin{array}{l}\text { Bale } \\
\text { Penyimpen } \\
\text { an }\end{array}$ \\
\hline
\end{tabular}

History /Literacy

History /Literacy

Bale

Agung

Temple

Megalithic/Prehistoric

Dalem Mecantel

Temple

Megalithic/Prehistoric

Dalem

Mecantel

Temple 20 2

7

1


Over the ancient relic is part of the human culture of the past and are evidence Authentik never unbeatable as an answer or human ideas on the challenges of the natural environment on the one hand and the increasing needs of daily life. Laksmi, et al (2011:1) also argue that ancient relics as a result of human creativity, initiative, and work have noble values that can be learned to be used as guidelines for people's lives today.

Most of the ancient relics found in the Desa Pakraman Selulung are the result of prehistoric/megalithic culture. The existence of harmonious acculturation between the ancient relics of the megalithic era with the culture of the Hindu community makes the ancient relics in the Desa Pakraman Selulung have its own uniqueness compared to ancient relics in other places. According to Sutaba (1980: 28-29) what attracted the attention of megalithic relics in the Desa Pakraman Selulung is the assumption or belief of the local population, that these megalithic forms are still considered sacred and sacred, and the so-called Hindu temples in the area are actually forms of a combination of megalithic holy places with Balinese Hindu temples. The following are the characteristics of megalithic relics found in Desa Pakraman Selulung, Kintamani, Bali.

\section{Punden Berundak}

Punden berundak are derived from the word Punden which is Javanese, meaning a glorified person (Sagimun, 1987: 48), while the notion of terraces or steps according to the Big Indonesian Dictionary has a multilevel meaning (Development Team: 2008: 1987). ). So, Punden Berundak is a sacred building where the worship of ancestral spirits is tiered (Sagimun, 1987: 48; Asmito, 1992: 17). Punden Berundak located in the Desa Pakraman Selulung is one of the archaeological relics of the megalithic period in Bali. There are five punden terraces, namely two in Mihu Temple and two in Candi Temple and one in Bale Agung Temple.

The punden relic in the Desa Pakraman Selulung is known as Madya which means "big mountain" or Madya is a "symbol of a big mountain". Meanwhile, the term punden terraces is only used by researchers or foreigners. In addition, in mentioning the Punden Berundak in Desa, Pakraman Selulung human names are also used, such as Madya Pelinggih I Ratu Gede Kemulan, Madya Pelinggih I Ratu Hamlet Jegir, Madya Pelinggih Ratu Gede Kanginan, and Madya Pelinggih Ratu Gede Makarang. The meaning of "pelinggih" here has the meaning of "ancestors who occupy, inhabit, reside" in the punden berundak building. To find out more details about the characteristics of Punden Berundak in Pakraman Selulung Village, it can be seen from the explanation below.

1. First, Punden Berundak or Madya Pelinggih Ratu Gede Kanginan found at Mihu Temple. This Punden Berundak consists of 5 (five) levels, with a rectangular base plan, and is made of solid stone and is combined with a few bricks attached with soil adhesive. The condition of the Punden Stairs from the bottom to the top on each step/level there is a terrace, the higher you go the smaller it is and at the top there are menhirs (Implementation Team, 2012: 34; Susila, et al, 2007: 7; Sutedja and Muliarsa, 1990: 8 ).

2. Second, Punden Berundak or Madya Pelinggih Ratu Gede Mekarang which is located at Mihu Temple. This Punden Berundak is located \pm 1.50 meters to the east of theBerundak Berundak Queen Gede Kanginan Pelinggih. The Punden Berundak Pelinggih Ratu Gede Mekarang consists of 4 (four) levels, made of solid stone pairs with soil adhesive (Susila, et al, 2007: 16). This building also has a basic rectangular shape with terraces on each level and at the top of the building there are menhirs (Sutedja and Muliarsa, 1990: 7; Susila, et al, 2007: 16).

3. Third, Punden Berundak or Madya Pelinggih Ratu Gede Kemulan which is located in the Candi Temple. This Punden Berundak has 5 (five) levels, the higher the level it gets smaller and at the top there are menhirs (Sutedja and Muliarsa, 1990: 7; Implementing Team, 2012: 33). The base of the Punden Berundak is rectangular in shape and is made of a pair of padas (paras stone) with a soil adhesive (Susila, et al, 2007: 17). 
4. Fourth, Punden Berundak Madya Pelinggih Ratu Hamlet Jegir is located in Candi Temple. This Punden Berundak has 5 (five) levels, the higher the level the smaller and at the top there is an upright stone resembling the stem/handle of a clapper and a rectangular base (Sutedja and Muliarsa, 1990: 6; Implementing Team, 2012: 33; Susila, et al, 2007: 23). The position of the building is located in the northwest courtyard of Punden Berundak Pelinggih Ratu Gede Kemulansolid, and is made of stone with soil adhesive.

5. Fifth, Punden Berundak at Bale Agung Temple. The Punden Berundak in Bale Agung Temple are one piece with steps/steps consisting of 3 (three) levels, and are on a rock with a height of $25 \mathrm{~cm}$, a length of $162 \mathrm{~cm}$, and a width of $124 \mathrm{~cm}$ (Implementation Team, 2012: $35)$. At the top of the Punden Berundak building at Bale Agung Temple there is a hole with a depth of $25 \mathrm{~cm}$, and a diameter of $20 \mathrm{~cm}$. It is possible that the hole is a place to put a menhir (Sutedja and Muliarsa, 1990: 5).

From this explanation, it can be concluded that the Punden Berundak located in the Desa Pakraman Selulung is one of the relics of the megalithic or prehistoric era whose existence is still preserved by local residents as a place to worship ancestral spirits. The worship of ancestral spirits can be seen from the human names used by the people of Desa Pakraman Selulung to refer to the punden berundak, namely Madya Pelinggih I Ratu Gede Kemulan, Madya Pelinggih I Ratu Hamlet Jegir, Madya Pelinggih I Ratu Gede Kanginan, and Madya Pelinggih I Ratu Gede Makarang. At the top of the terrace there are also standing stones / menhirs. The function of menhirs is to describe the spirits of ancestors who are far away on a mountain. The meaning of the menhir above the Punden Berundak symbolizes the stages that must be passed in order to reach the highest place (where the ancestors are) (Soekmono, 1984: 78).

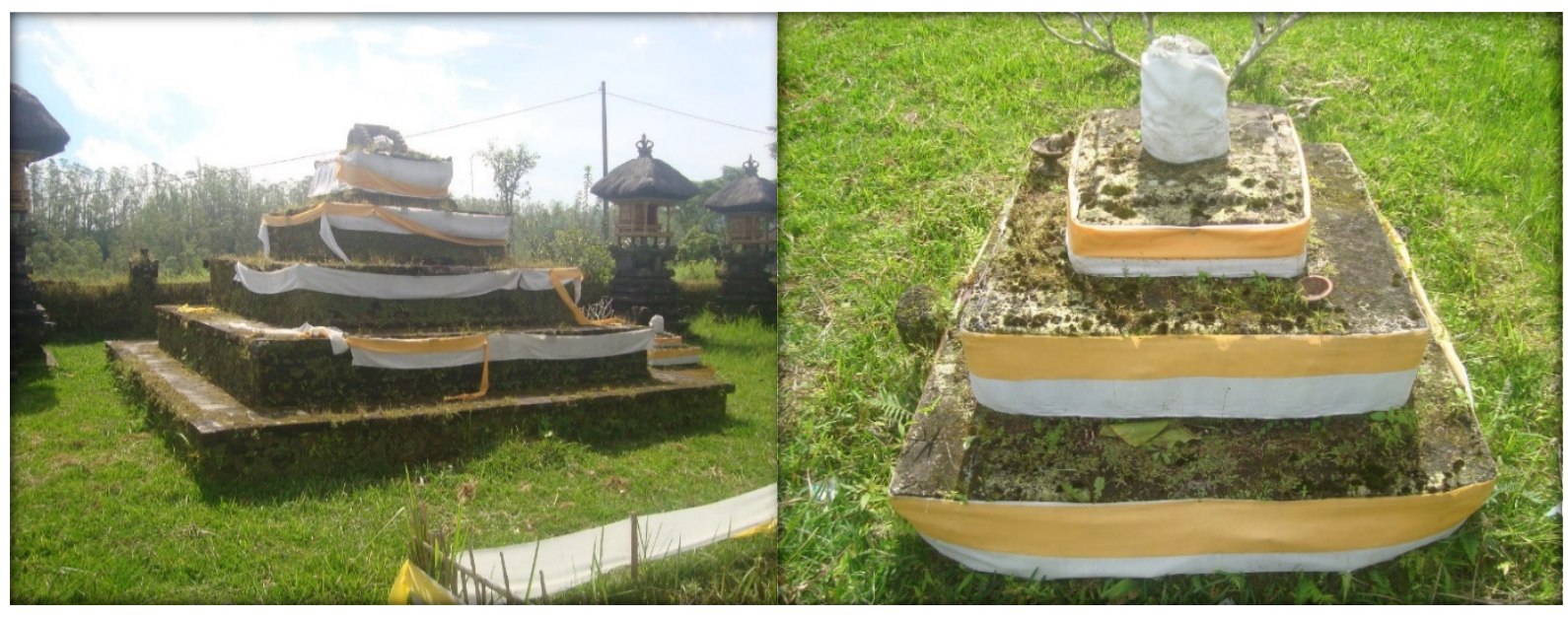

Figure 1. Punden Berundak Pelinggih I Ratu Gede Kanginan (left) and Punden Berundak pelinggih I Ratu Gede Makarang (right) at Mehu Temple 


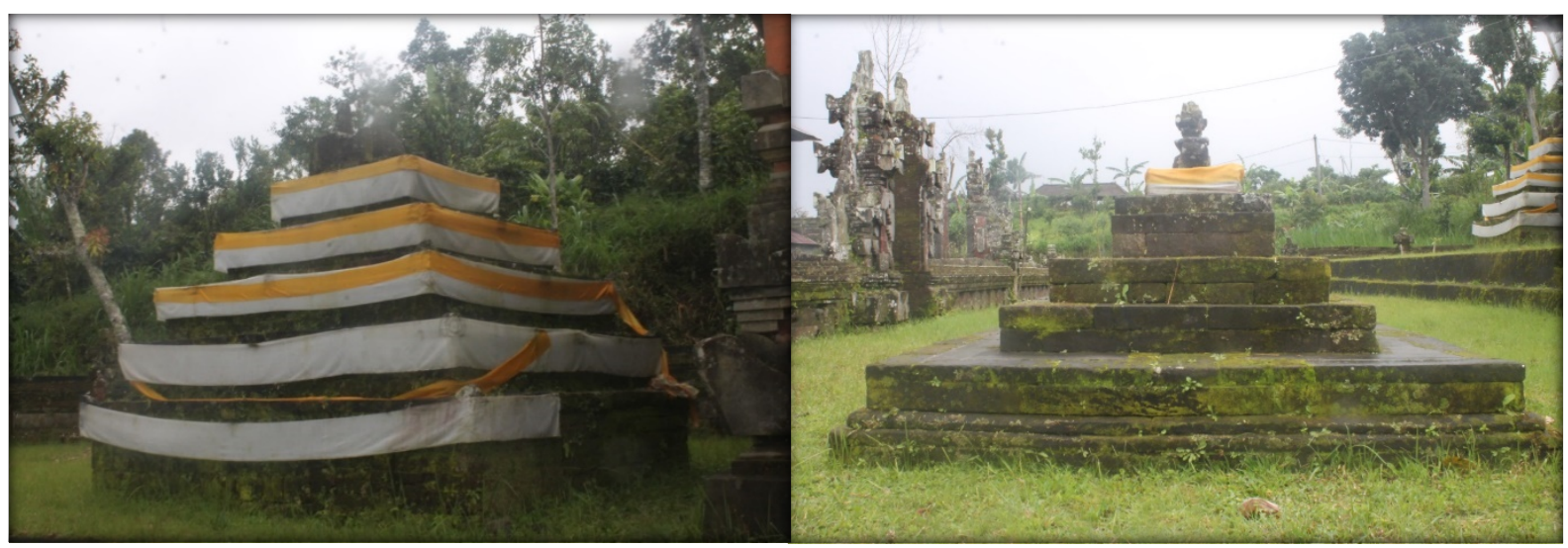

Figure 2. Punden Berundak Pelinggih Associate Sublime /Pelinggih I Ratu Gede Kemulan (left) and Punden Berundak Pelinggih AssociateAlit/Ratu Hamlet Jegir (right) at Candi Temple

\section{Arca Megalitik}

Arca Megalithic are megalithic buildings that symbolize ancestors (Asmito, 1992: 17).

Soekmono (1984: 73) also explains that arca megalithic are buildings that may symbolize ancestors and become idols. Some megalithic statues are made of wood and some are made of stone as described by Kusumawati and Sukendar (2003: 9). Sukedar further explained (in Yuliati, 2005: 74), that megalithic statues are simply carved statues that do not show the influence of Hindu-Buddhist religion but are related to ancestral spirits.

Megalithic statues found in Desa Pakraman Selulung are in Ulun Suwi Temple which is part of the Tanjungan Hamlet, Selulung Service Village, Kintamani District, Bangli. The total number of statues in Ulun Suwi Temple is (8) eight statues, and are in two different storage areas. Place in the form of two Bale or building called Bale pegat or Bale Selulung. According to a research report by Sutedja and Muliarsa (1990) explaining the characteristics of 8 (eight) Megalithic Statues found in 2 (two) Bale Pegat at Ulun Suwi temple, Desa Pakraman Suwi namely as follows:

1. In Bale Pegat I there are 4 (four) Arca Megalithic with the following characteristics:

a) Arca A, placed on a pedestal measuring $8 \mathrm{~cm}$ high, $20 \mathrm{~cm}$ long, $21 \mathrm{~cm}$ wide, and $61 \mathrm{~cm} \mathrm{high}$. The attitude of the statue is standing rigidly with the right leg folded and resting on the knee of the left leg, the face is worn, the hair is in a bun, the ears are long wearing earring, the right hand holds the breast and the left hand holds something.

b) Arca B, is on a pedestal measuring $9 \mathrm{~cm}$ high, $27 \mathrm{~cm}$ long, $23 \mathrm{~cm}$ wide, and $60 \mathrm{~cm}$ high. His demeanor is stiff, his face is round, his eyes are worn out, his nose is sharp, his lips are thick, his ears are long with earring, and his hands are crossed over his stomach.

c) Arca C, located on a pedestal measuring $10 \mathrm{~cm}$ high, $27.5 \mathrm{~cm}$ long, $20 \mathrm{~cm}$ wide and $56 \mathrm{~cm}$ high. His demeanor is stiff, his face is oval, his hair is in a bun, his ears are long with earring, his hands are joined in front of his chest in an intertwined manner, his belly is distended, and his legs are crossed like cross-legged.

d) Arca D, this statue is on a pedestal measuring $7 \mathrm{~cm}$ high, $29 \mathrm{~cm}$ long, $28 \mathrm{~cm}$ wide, and the height of the statue is $51 \mathrm{~cm}$. His attitude is stiff, oval face, closed eyes, sharp nose, thick lips, long ears wearing earring. This statue sits with the right hand holding the knee of the right leg which is folded over the knee of the left leg and the left hand holding the thigh of the left leg (Sutedja and Muliarsa, 1990: 3-4).

2. In Bale Pegat II there are 4 (four) Arca Megalithic with the following characteristics:

a) Arca A, located on a pedestal measuring $8 \mathrm{~cm}$ high, $24 \mathrm{~cm}$ long, $21 \mathrm{~cm}$ wide, and the height of the statue is $51 \mathrm{~cm}$. His attitude is stiff, oval face, long ears wearing earring, closed eyes, thick lips. The statue sits with the legs crossed with the right leg above, the hands crossed over the chest, and shows the female genitalia. 
b) Arca B, is on a pedestal measuring $7 \mathrm{~cm}$ high, $20 \mathrm{~cm}$ long, $14 \mathrm{~cm}$ wide, and $46 \mathrm{~cm}$ high. His attitude is stiff, his face is worn, his ears are long wearing earring, his hands are crossed over his breasts, and his legs are crossed like cross-legged.

c) Statue C, located on a pedestal measuring $10 \mathrm{~cm}$ high, $25.7 \mathrm{~cm}$ long, $21.5 \mathrm{~cm}$ wide and 44 $\mathrm{cm}$ high. His demeanor is stiff, his face is oval, his ears are long with earring, his eyes are half closed, his lips are thick, his breasts are protruding, his hands are covering his stomach, and his legs are crossed like cross-legged.

e) Arca D, on a pedestal measuring $10 \mathrm{~cm}$ high, $16.3 \mathrm{~cm}$ long, $21 \mathrm{~cm}$ wide, and $30 \mathrm{~cm}$ high. His attitude was stiff, round face, hair in a bun, eyes half closed, and thick lips. The statue is in a sitting position with the left leg dangling, while the right hand in the waramudra attitude and the left hand holding the right foot (Sutedja and Muliarsa, 1990: 3-4).

When viewed in terms of art, the arca megalithic found in Ulun Suwi Temple do not show the aesthetic value of art in it. However, as a result of the megalithic tradition, the megalithic statues have their own style which was supported by the natives in the Desa Pakraman Selulung in prehistoric times. The simplicity of the forms of the statues above, does not mean that the sculptors or makers are less proficient, but that what is highlighted in the manufacture of megalithic statues is their magical religious values. So, the characteristics of prehistoric art are also determined by the factors that support its appearance, especially belief, so that the appearance of its shape is less concerned with anatomical proportions. This is in accordance with Sumiati's opinion (in Gede, 1994: 9) which states that the elements that are prioritized are in terms of belief, so that megalithic statues emphasize magical symbolic meanings rather than anatomical accuracy.

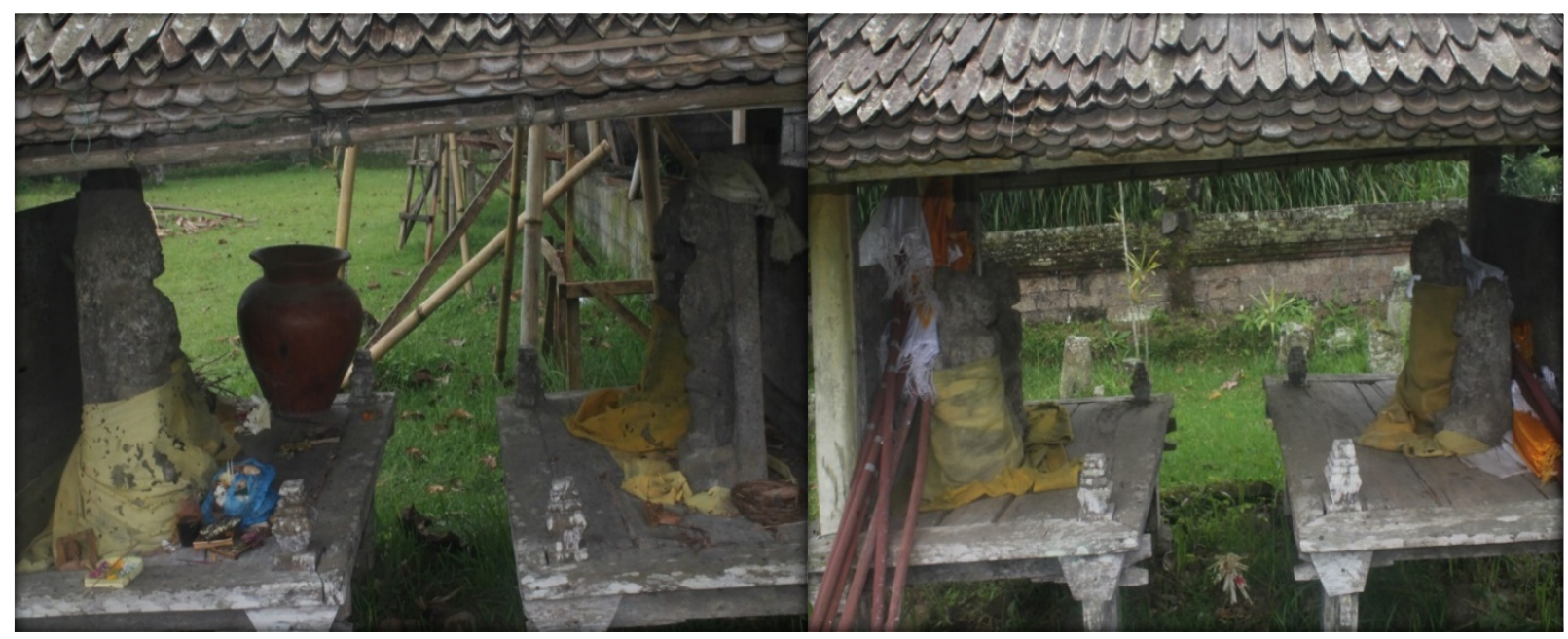

\section{Menhir}

Figure 3. Eight Arca Megalithic at Ulun Suwi Temple

The term menhir comes from the word men meaning stone, while hir means upright or standing, so menhir means erect or standing stone (Sagimun, 1987: 42). Menhir is also interpreted as a memorial that symbolizes the ancestors so that they are worshiped (Asmito, 1992: 17). Stone altar or menhirs are also interpreted as "commemorative pillars" (Ardana, 1980: 16). Suastika (2005: 87) also explains that a menhir is an upright stone or standing stone that is planted on the ground, consisting of a single stone or more. Meanwhile, according to Soekmono (1984: 72) menhirs are poles or monuments, which were erected as a warning sign and symbolize the spirits of the ancestors, so that they become objects of worship. Based on 
the explanations of several experts above, it can be concluded that menhirs are standing stones or standing stones that symbolize ancestors and are planted or stuck on the ground as a means of worshiping ancestral spirits.

The Menhirs located in the area of Desa Pakraman Selulungare one of several types of megalithic relics that are often found in temples in the Desa Pakraman Selulung. Menhirs / standing stones in the Desa Pakraman Selulung are located in two different temples, namely at Puseh Sinunggal Temple and at Ulun Suwi Temple. In addition, in 2017 several menhirs were also found lying down in the residents' gardens.

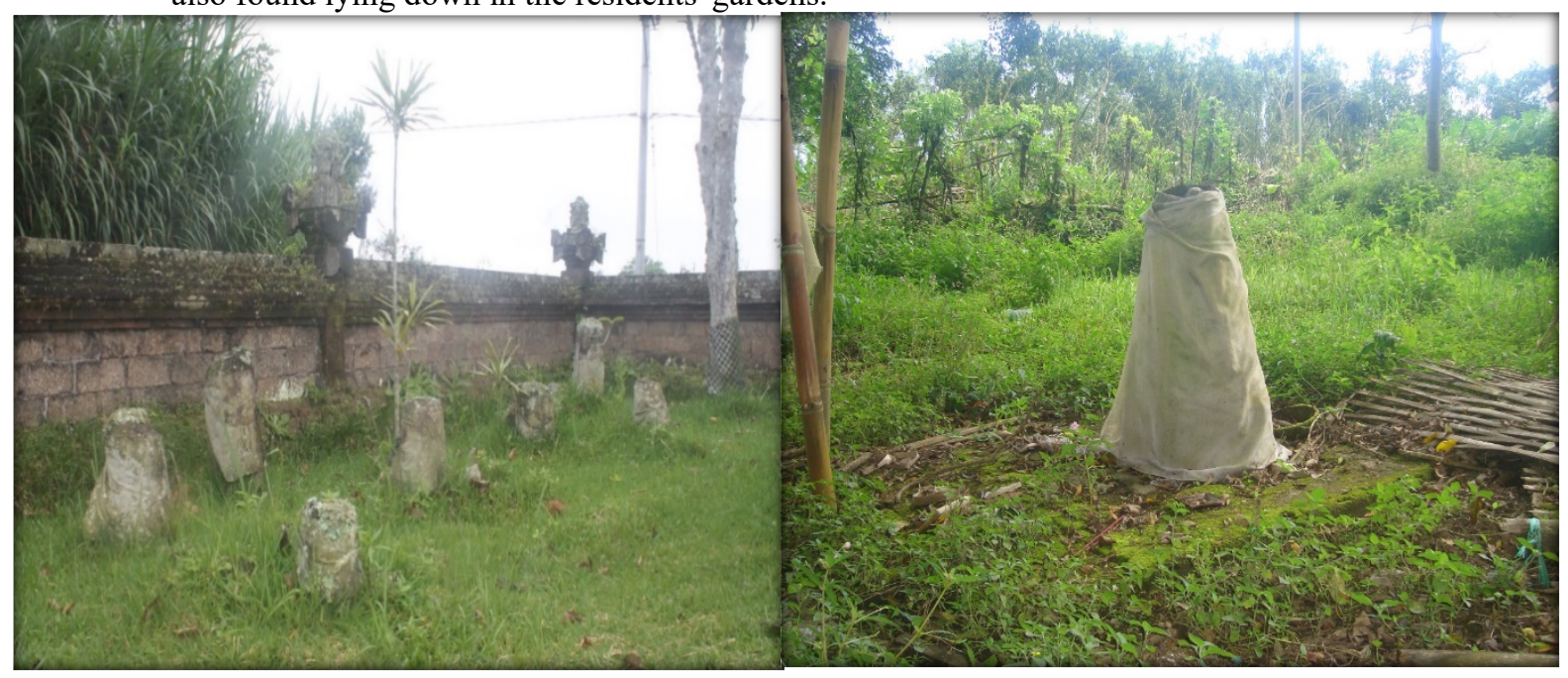

4. Sarcophagus

Figure 4. Menhirs in Desa Pakraman Selulung

Sarcophagus is a stone coffin or stone coffin to bury people from certain groups (Sagimun, 1987: 39). In general, the sarcophagus in Bali is clearly a burial container with various shapes and variations. Regarding the meaning of the shape of the sarcophagus, Purusa (2002: 2-3) explains that when viewed from the overall shape without paying attention to the protrusions of each sarcophagus, it can almost be said that the general shape resembles a boat, this binds that people who spread This sarcophagus culture comes from across the ocean.

In the Ddesa Pakraman Selulung, two sarcophagi were found. First, the Taked Sarcophagus which was found in Banjar Taked, Selulung Village, Kintamani, Bangli. This ancient relic is now stored in the Gedong Arca Bedulu Museum, Gianyar. The Taked Sarcophagus is $116 \mathrm{~cm}$ long, $115 \mathrm{~cm}$ high and $69 \mathrm{~cm}$ wide. This sarcophagus consists of 2 (two) parts, namely the container and the lid of a plain shape, on the front and back there are carvings in the form of protrusions (round) each of 2 (two) pieces on the container and lid. Second, the sarcophagus was found by residents in 2016 in one of the residents' gardens. Its characteristics are almost the same as the Taked Sarcophagus, which consists of 2 (two) parts, namely the container and the lid of a plain shape. 


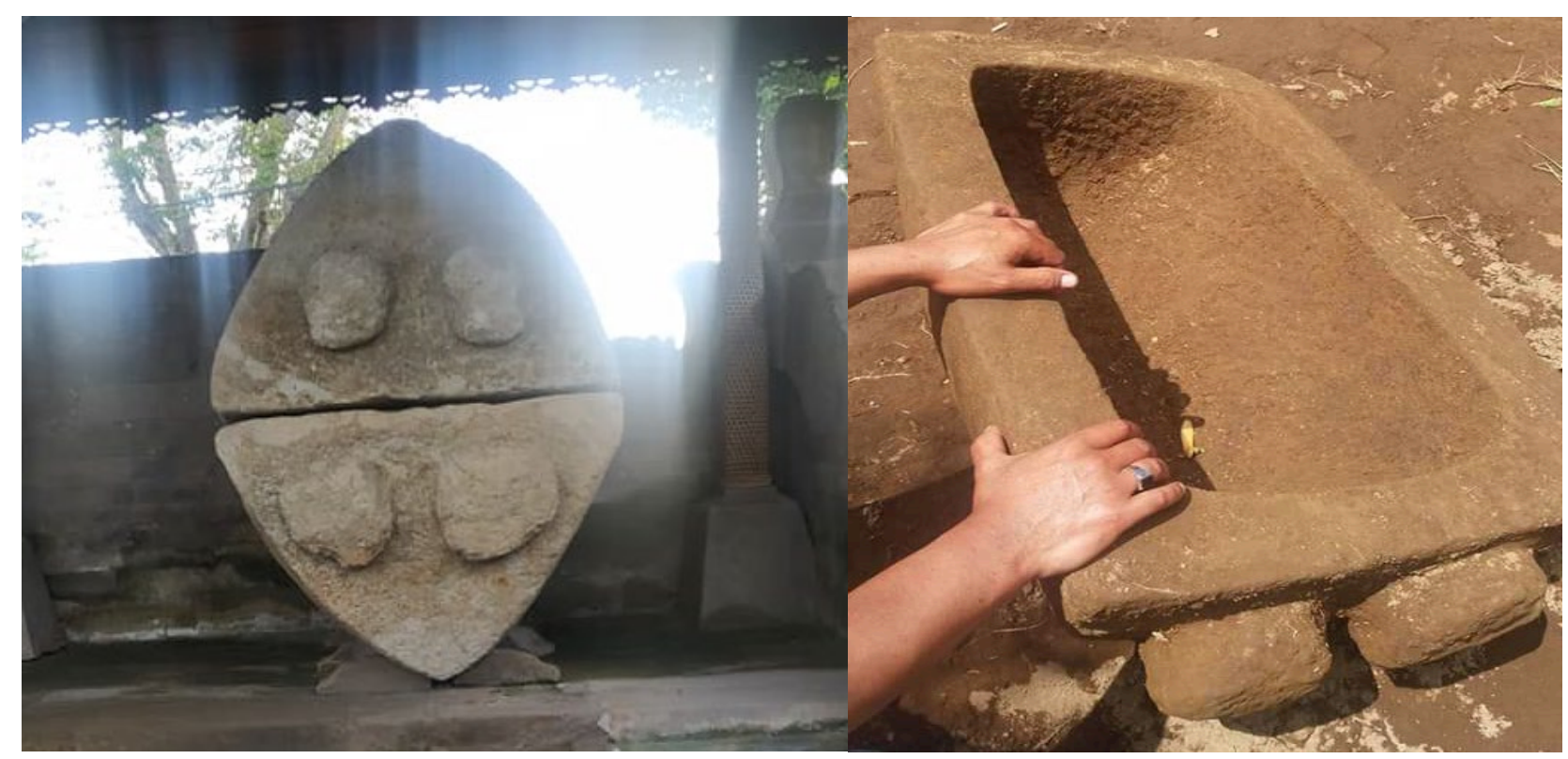

Figure 5. Sarcophagus in Desa Pakraman Selulung

\section{B. HISTORY LEARNING INNOVATION BASED ON LIVE VIRTUAL LEARNING}

History learning with the model Live Virtual Learning can be done with various online media/applications, such as Youtube, Instagram, Whatsapp, google meet, zoom meetings and other applications. There are various advantages / advantages in the implementation of history learning using Live Virtual Learning, namely:

1. Learning history using Live Virtual Learning can be accessed easily by students. Only with a smartphone or computer/laptop device that is connected to the internet, students can take lessons anywhere and anytime, without being limited by space and time.

2. Learning history by using Live Virtual Learning can reduce the cost of education. Learning can be done using only a smartphone simple and students don't have to worry about missing out on the subject matter considering that the recordings Live Virtual Learning previously performed by the lecturers can be accessed again by students. Meanwhile, through Live Virtual Learning, students do not need to come to campus to carry out face-to-face learning, thus saving on transportation costs, consumption and even housing costs for students from out of town.

3. Learning history using Live Virtual Learning makes the learning time of students more flexible and more relaxed so as to provide learning comfort for students.

4. History learning using Live Virtual Learning provides wider opportunities for students to explore additional information related to the material presented by the lecturer, thus enabling students to develop.

The implementation of history learning using Live Virtual Learning also in principle has various weaknesses / shortcomings such as requiring a stable internet connection, students must incur additional costs to buy smartphones or computer/laptop devices and internet quotas, reduced interaction between lecturers and students, students can all the time lose focus in learning due to lack of supervision, and others. However, some of these weaknesses can actually be anticipated by doing careful preparation before starting the lesson.

The following are the stages in learning history using Live Virtual Learning including preparation (planning), implementation process, and evaluation.

\section{Preparation (Planning)}

\section{a. Making Semester Learning Plans (RPS)}


Creating a history learning plan based on Live Virtual Learning is the first step in preparation for learning. Basically, the design of history learning based on Live Virtual Learning includes the following elements: a) learning objectives; b. learning materials; c learning methods; d. learning resources; e learning media; f. Time Allocation.

\section{b. Preparation of Learning Facilities and Infrastructure}

\section{1) Internet Network}

The strength of the internet network is the most important thing to know and prepare for use in history learning based on Live Virtual Learning, considering that whether or not online learning is smooth is largely determined by the strength of the internet network. This is of course also related to the position of students and lecturers when carrying out learning. If students/lecturers are far from the city and live in remote areas or villages where it is difficult to receive internet signals, then this will affect the smooth learning of Live Virtual Learning. Therefore, teachers need to know the strength of the student internet network to make it easier to choose the learning media used.

\section{2) Preparation of Electronic Devices}

Devices needed to support history learning based on Live Virtual Learning include mobile phones with good camera quality, stable internet network, microphone, and tripod. In addition, to maximize the learning process, lecturers also need to prepare field assistants to help take pictures/videos.

\section{3) Student Conditions and Positions}

In learning history based on Live Virtual Learning, lecturers need to know the condition of students, both in terms of their ability to purchase quotas, communication tools they have, ability to use applications, availability of quotas, and so on. Likewise the position of students, whether they live in the city or far from the city. This condition and position is important for the teacher to know so that it is easy to determine the learning media to be used.

\section{4) Making Agreements with Students before Learning}

After making a history learning plan based on Live Virtual Learning, as well as preparing matters related to learning, the next step is to make an agreement with students. Agreements with students need to be made so that in the next stage, the learning implementation process can run smoothly. The things that need to be agreed are:

a) Students and lecturers agree on a schedule for the implementation of Live Virtual Learning.

b) Students and lecturers agree on media/applications online that will be used in Live Virtual Learning, whether using Youtube, Instagram, Whatsapp, google meet, zoom meetings or other applications

c) Students create Whatsapp groups to make it easier to communicate when there are problems/interferences in learning.

d) Ensure that students have/have downloadedmedia/applications online that have been determined as historical learning media based on Live Virtual Learning.

e) The lecturer conveys the procedures/rules for implementing Live Virtual Learning or learning SOPs. This SOP helps students know the agreed rules during Live Virtual Learning and can be a shared commitment between lecturers and students.

\section{Implementation Process}

The implementation stage is the most important and decisive stage, because the implementation process has a major influence on the achievement of the learning objectives that have been formulated, including in history learning based on Live Virtual Learning. Before 
starting the lecture, the things that need to be considered are the lecturers must be at the location of other learning resources that will be used asobjects Live Virtual Learning and prepare all kinds of necessary devices. The following is an example of the syntax of learning history based on Live Virtual Learning by using theapplication Facebook and by utilizing megalithic relic's in Desa Pakraman Selulung as a learning resource.

\section{a. Preliminary Stage of Live Virtual Learning}

In the preliminary stage of learning history based on Live Virtual Learning, there are several steps that can be taken, such as:

1) Lecturers open theapplication Facebook ondevices mobile.

2) On the home page choose theoption (Live StreamingLive Streaming).

3) Next, theapp Facebook will ask for permission to access the camera and also microphone, click thebutton allow.

4) Then the lecturer can also choose the camera you want to use to record video live broadcast, can be with the front camera or front camera.

5) In addition, lecturers can also add filters, tag friends and also set privacy.

6) When all the preparations are complete, just click the button Start Live Video (Live Streaming).

7) Lecturers greet, open lectures, and conduct attendance through live video broadcasts.

8) The lecturer explains the learning objectives according to the lesson plans that have been made.

\section{b. Core stage of learning Live Virtual Learning}

At the core stage of learning the lecturer explains directly (Live Virtual Learning) megalithic relics in Desa Pakraman Selulung, covering aspects of the types of relics, characteristics of relics, functions of relics, state of relics, and other aspects. At this stage the lecturer also needs to pay attention to the chat feature during Live Streaming to see how students respond to the material presented. If there is material that is not clearly understood by students, the lecturer needs to re-explain the material.

\section{c. Tahap Akhir pembelajaran Live Virtual Learning}

At the final stage of the lecture the lecturer asks for responses or questions from students regarding the material that has been delivered through Live Virtual Learning. Questions or responses from students can be submitted by students through the feature chat.

\section{Evaluasi}

Assessment is a series of activities to obtain, analyze, and interpret data about student learning processes and outcomes that are carried out systematically and continuously, so that they become meaningful information in decision making (Isdisusilo, 2012: 21). Referring to the use of megalithic relics in Desa Pakraman Selulungas a learning resource based on Live Virtual Learning using theapplication Facebook above, the types of assessments that can be used are quizzes, assessment of the activeness of the learning process (cognitive), assessment of affective observations, and assignments.

\section{Conclusion}

Learning history occupies a very important position as a medium to strengthen national identity which is one of the main assets in building the nation now and in the future. Through history learning, it means that we will be able to know and appreciate human development in the past, present and from the results of past experiences, a very valuable lesson can be drawn. However, if one observes the practice of teaching history, one often gets the impression that history lessons are not interesting, and even tend to be boring. Therefore, the innovation of 
learning history by utilizing digital technology today is a necessity. On another aspect, the Covid-19 pandemic has also "forced" educators (teachers and lecturers) to always innovate in presenting history learning that is in accordance with the characteristics of learners during the COVID-19 pandemic.

One of the innovations in history learning is to use live virtual learning. Through history learning based on live virtual learning, it will provide various kinds of facilities for students, such as teaching and learning activities that can be carried out anywhere and anytime, cheaply, student learning time becomes more flexible and more relaxed, and provides the widest opportunity for students to develop their knowledge. Through live virtual learning in history learning, it also allows lecturers to bring learning resources more realistically into classrooms virtual. This of course will improve the quality of learning and make it easier for students to absorb every material presented by the lecturer.

\section{References}

[1] Ahmad, A., dan Jinggan, N. 2015. Pengaruh Kompetensi Kemahiran Guru Dalam Pengajaran Terhadap Pencapaian Akademik Pelajar Dalam Mata Pelajaran Sejarah. Jurnal Kurikulum \& Pengajaran Asia Pasifik (JUKU), Bil. 3, Issue 2. pp. 1-11

[2] Ardana, I Gusti Gede. 1980. Unsur Megalitik Dalam Hubungan Dengan Kepercayaan Bali. Dalam Pertemuan Ilmiah Arkeologi. Jakarta: Offset PT Rora Karya. pp. 13-26

[3] Asmito. 1992. Sejarah Kebudayaan Indonesia. Semarang: IKIP Semarang Press

[5] Garvey, Brian dan Mary Krug. 2015. Models of History Teaching in the Secondary School "Model-Model Pembelajaran Sejarah Di Sekolah". Dian Faradilla (Editor). Yogyakarta: Ombak

Gede, I Dewa Kompiang. 1994. Arca Sederhana Dalam Kehidupan Masyarakat Ubung: Tinjauan Tentang Fungsi. Dalam Forum Arkeologi. Editor: I Made Sutaba. Denpasar: Balai Arkeologi. pp. 6-15

[6] gak cukup ya. Kontribusi Pendidikan Sejarah dalam Pengembangan Modal Sosial untuk Mewujudkan Nasionalisme. Internasional Seminar Proceedings 2015 with theme "Contribution of History for Social Sciences and Humanities". Ed. Dewa Agung G.A. Editor: Ari Sapto, dkk. Social Science Faculty of Universitas Negeri Malang: Malang. pp. 103-107

[7] Isdisusilo. 2012. Panduan Lengkap Membuat Silabus dan RPP. Bandung: Mata Pena

[7] Kusumawati, Ayu dan Haris Sukedar. 2003. Sumba, Religi dan Tradisinya. Denpasar: Balai Arkeologi Denpasar

[19] Laksmi, dkk. 2011. Cagar Budaya Bali: Menggali Kearifan Lokal Dan Model Pelestariannya. Denpasar: Udayana University Press

[20] Lisman, F., Primawati, Waskito, dan Sari, D. Y. 2021. Kelebihan dan Kekurangan Sistem Pembelajaran Daring Dari Perspektif Guru dan Siswa Di SMK 2 Payakumbuh", VOMEK: Jurnal Vokasi dan Mekanika. Vol. 3, No. 1. pp. 72-76

[21] Nengrum, T. Y., Solong, N. P., dan Iman, M. N. 2021. Kelebihan dan Kekurangan Pembelajaran Luring dan Daring dalam Pencapaian Kompetensi Dasar Kurikulum Bahasa Arab di Madrasah Ibtidaiyah 2 Kabupaten Gorontalo. Jurnal Pendidikan. Volumen 30, Nomor 1. pp.1-12

[6] Purnomo, Agus, dkk. 2016. Pengembangan Pembelajaran Blended Learning Pada Generasi Z. Dalam Habsari, Novi Triana. 201576

[7] Purusa, M. 2002. Relief Manusia Kangkang Pada Sarkofagus Selat, Buleleng. Dalam Forum Arkeologi. Denpasar: Balai Arkeologi Denpasar

[8] Sagimun, M. D. 1987. Peninggalan Sejarah Tertua Kita. Jakarta: CV Haji Masagung 
[9] Saleh, N., et all. 2018. Pemanfaatan QR-Code sebagai media pembelajaran Bahasa Asing pada Perguruan Tinggi di Indonesia. In Ntional Seminar Dies Natalis UNM ke 57. pp. 253-260

[10] Sayono, Joko. 2013. Pembelajaran Sejarah di Sekolah: Dari Pragmatis ke Idealis. Jurnal Sejarah dan Budaya. Volume 7, Number 1. pp. 9-17

[11] Soekmono, R. 1984. Pengantar Sejarah Kebudayaan Indonesia I. Yogyakarta: Kanisius

[12] Suastika, I Made. 2005. Pemujaan Ratu Gede Penabanan Merupakan Tradisi Megalit Berlanjut di Desa Tejakula. In Archaeology Forum. Denpasar: Balai Arkeologi Denpasar. pp. 82-97

[13] [Subdistric] hn Subir, M., S. 2020. Fungsi Virtual Learning Dalam Sistem. Transformasi: Jurnal Studi Agama Islam. Volume 13, Number 1. pp. 20-37

[14] Susila, I Wayan, dkk. 2007. Laporan Studi Teknis Pura Miyu dan Pura Candi Desa Selulung, Kecamatan Kintamani, Kabupaten Bangli. Denpasar: Balai Pelestarian Peninggalan Purbakala Bali, NTB, dan NTT Province

[15] Sutaba, I Made. 1980. Beberapa Catatan Tentang Tradisi Megalitik Di Bali. In Scientific Archeology Forum. Jakarta: Offset PT Rora Karya. pp. 27-37

[16] Sutedja, I Wayan dan I Wayan Muliarsa. 1990. Laporan Pengumpulan Data Kepurbakalaan Di Desa Selulung dan Sekitarnya. Gianyar: Suaka Peninggalan Sejarah dan Purbakala Bali-NTB-NTT-TIMTIM

[17] Tim Penyusun. 2008. Kamus Bahasa Indonesia. Jakarta: Pusat Bahasa Departemen Pendidikan Nasional

[30000] Yuliati, Luh Kade Citha. 2005. Kajian Seni Pada Arca Sederhana di Pura Batu Melawang Nusa Ceningan. Dalam Forum Arkeologi. Denpasar: Balai Arkeologi Denpasar. pp. 70-81 